\title{
Reconnaissance of the Function of Social Media on Study Habits Of Undergraduate Students in the University of Cape Coast.
}

\author{
Ruth K. Annan-Brew , Philip Nartey \\ (PhD) Dep. Of Education and Psychology University of Cape Coast \\ (MPhil) Dep. Of Education and Psychology University of Cape Coast
}

\begin{abstract}
The world today is celebrating the improvements in communication technology which has broadened the scope of communication through Information and Communication Technologies (ICTs). Modern Technology in communication no doubt has turned the entire world into a "Global village". But as it is, technology like two sides of a coin, bring with it both negative and positive sides. The study examined the function of social media on students' study habit. The study employed a descriptive survey design with a quantitative approach. The stratified and purposive sampling techniques were used to select 217 out of 245 students from level $300(n=111)$ and $400(n=106)$ ) undergraduate Psychology students. Researchers'designed questionnaire titled "Usage of Social Media Questionnaire" (USMQ) and "Students Study Habits Questionnaire" (SSHQ) with Cronbach's Alpha reliability coefficients of 0.74 and 0.83 respectively were used to collect data for the study. WhatsApp and Facebook were the predominant social media sites students were exposed to. Students were found to be addicted to social media usage. The study revealed no statistically significant differences in the usage of social media with regards to gender and age. Social media was found to significantly influence the study habits of respondents. Specifically, increased usage of social media resulted in negative study habit. It was recommended that academic counsellors together with the management of tertiary institutions should map out strategies (eg., integration of topics on the pros and cons of social media use in the lecture theatre in various courses of study by lecturers and restriction of social media use during lectures by students) to reduce students' addiction to social media platforms. It also recommended to students to allow quality time for studies and use of social media for the right purposes, especially their academic studies.
\end{abstract}

\section{Keywords: Social media, Study Habit, WhatsApp, Facebook.}

\section{Introduction}

In the academic world, social media is an educational tool that can entice students inside and outside lecture theatres and influence their total success. Using social media can have adverse effects on the students like wasting time, inattentiveness in class, lateness and social problems which have consequences on academic performance and study habits. Notwithstanding, social media has become ever-present in today's globalized world as a result of its numerous importance in student's communication and information.

It appeals to people from all walks of life, particularly students, for a variety of purposes irrespective of some adverse effects that their use may have on their academic performance. Modern Technology in communication no doubt has turned the entire world into a "Global village". But as it is, technology like two sides of a coin, bring with it both negative and positive sides. It helps people to be better informed, enlightened, and abreast with world developments. Technology exposes mankind to a better way of doing things. Social media sites include Twitter, Yahoo Messenger, Facebook Messenger, Blackberry Messenger (BBM), WhatsApp messenger, Skype, Google Talk, Google Messenger etc. These social media sites are used by most people to interact with old and new friends, physical or internet friends (Asemah \& Edegoh, 2012). 
Hudson (2007) observed that the power of digital media in general, and digital writing in particular, has begun to reinforce the sense of a new social order and bears central importance to those concerned with the welfare and education of children and young people. According to Blankenship (2011), interactive, communityfocused online tools like Facebook, Twitter, Skype, YouTube, blogs, wikis, and educational software Blackboard are becoming more prevalent in the college classroom. Among college students, Facebook is also the most popular social media site (Blankenship, 2011; Lenhart, Purcell, Smith, \& Zickuhr, 2010). Such new digital applications of social media enable the users to connect and interact with one other in a virtual community (McCarthy, 2010). Such technology innovations are not only changing the users' way of communication but also revolutionizing the conditions of their literacy experiences and developing new practices (Reid \& Weigle, 2014)

Instead of students using social media for something more profitable, they spend their time chatting and making friends via social media and this might influence some aspect of their lives such as being redrawn from society, spending so much on buying airtime which could cost them financially, performing poorly in class, experiencing fatigue and among others. (Yeboah, \& Ewur, 2014).

Because they sometimes use social media sites alongside reading their books, however, they end up sitting behind their books for about three hours without reading two pages of their notes. It is also a common sight to see a student chatting insensitive and highly organized places like church, mosque and lecture venues when they should instead be paying attention. Some are so carried away that even as they are walking along the high way, they keep chatting, liking the post on Facebook, Twitter, Instagram etc., which may sometimes result in an accident (Allen, Ryan, Gray, McInerney, \& Waters, 2014).

The manufacturing and distribution of equally sophisticated cellular phones have complicated the situation, as students no longer need to visit a cybercafé before they send and receive messages (Asemah, Okpanachi, \& Edegoh, 2013). Attention has been shifted from visible to invisible friends, while important ventures like studying and writing might be affected in the process. This phenomenon has become a source of worry to many who believe in knowledge and skill acquisition (Sangwaan, 2019; Atteh, Assan-Donkoh, Mensah, Boadi, Badzi, \& Lawer, 2020).

In recent times, social media has become a major concern of parents, teachers, school administrators, etc. which is been measured as a possible variable that can influence how student go about their studies. This has been a worry for education stakeholders like parents, teacher and even educational administrators at large. It is therefore of great importance to explore some of the trending issues facing students' school lives as a result of social media. Students at all levels of learning now have divided attention to studies, as a result of available opportunities to be harnessed from social media. Whether these opportunities promote healthy school life is a question that needs to be answered. Thus, the problem this study investigates is the function of social media on tertiary students' study habit.

\section{Methodology}

This study aims to answer the question, "Reconnaissance of the function of social media on study habits of undergraduate Psychology students in University of Cape Coast, Ghana. The data for the analysis was gathered through a survey questionnaire distributed to 217 level 300 and 400 undergraduate Psychology students in the 2018/2019 academic session to obtain information about their experiences and the impact of using social media on their study habit. The respondents were required to offer information on their experiences in using social media tools for collaborative learning and engagement to improve their performance. From the distributed questionnaires within the one-month duration, 217 valid responses were returned. Means, standard deviation, percentages, frequencies, independent sample t-test and multiple regression were used to analyze the data. 


\section{Results and Discussion \\ Hypothesis One}

\section{Ho: There is no significant difference between male and female student usage of social media.}

This hypothesis sought to test whether male and female students differed in the level of use of social media. The independent samples t-test was used to test this hypothesis. Table 1 presents the details.

Table 1: Gender Difference in Social Media Usage

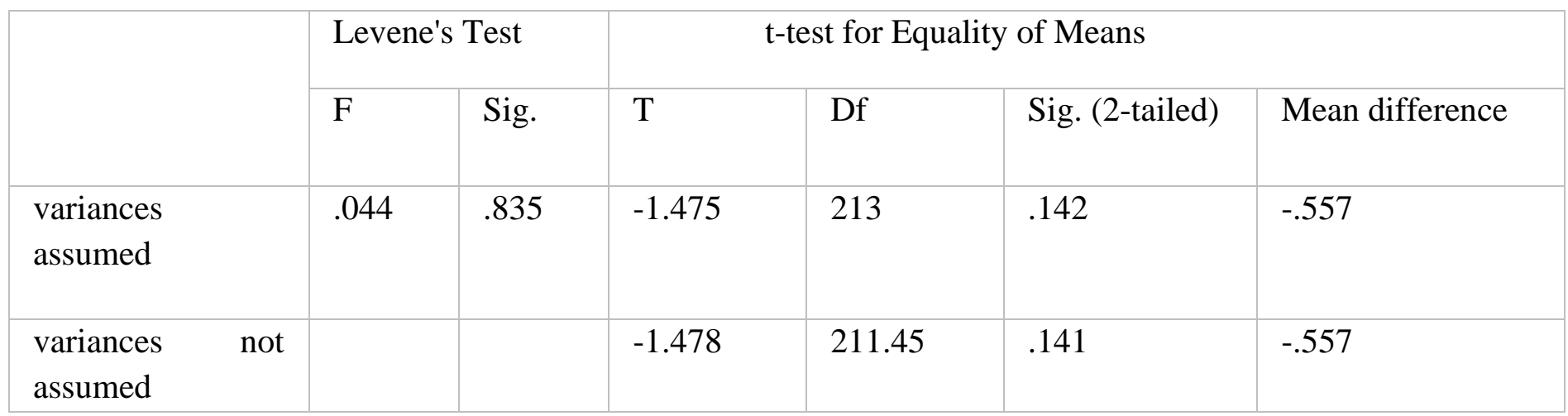

Male $(\mathrm{M}, \mathrm{SD})=10.73$, Female $(\mathrm{M}, \mathrm{SD})=(11.29,2.81)$

The results in Table 1 shows that there exists a non-significant gender difference in the use of social media, $t$ $(211.15)=-1.478, p=.141$. The findings of this study are inconsistent with that of Mazman and Usluel (2011) which showed a significant difference between male and female in the use of social media. Other studies have demonstrated that young men have been online more than young ladies earlier because of earlier types of innovation, for example, video or PC recreations (Lin \& Subrahmanyam, 2007). For other types of social media platforms, gender differences are less conclusive. There is some indication that men use internet forums and wikis more frequently (Kim, Sin, \& Tsai, 2014; Lim \& Kwon, 2010). Male students held more positive expectations of Wikipedia's accuracy and comprehensiveness (Lim \& Kwon, 2010). Others have posited that men are more task-oriented and less relational than women in their Internet and social media use (Lin \& Lu, 2011). On the strategies used for evaluating social media information, gender has been found to interact with problem-solving styles. Women with more effective problem-solving styles tended to check other users' reactions more frequently. This pattern is reversed for men (Kim \& Sin, 2014)

Several other studies have reported findings consistent with the findings of this study. Alnjadat, Hmaidi, Samha, Kilani and Hasswan (2019) and Rafferty (2009). for instance, found that girls are more likely than young men to post pictures of themselves and to discuss sexual action in open gatherings. For young ladies, social networking sites are principally put to fortify prior fellowships; for young men, the systems additionally give chances for flirting and making new companions (Raacke \& Bonds-Raacke, 2008)

Unlike this study, Merten and Williams (2009) found that young ladies are more probable than young men to share individual data about their day by day lives. Results of an ongoing study including Facebook, MySpace, and Xanga demonstrated that however most adolescents aged 13-17 utilized these sites for fun and positive reason, 55\% of young ladies shared any personal information, nervousness, and relationship issues (Williams \& Merten, 2009).

\section{Hypothesis Two}

Ho: Age does not have a significant influence on the use of social media.

This hypothesis sought to test whether age significantly influences the use of social media among university students. Simple linear regression was used to test this hypothesis. Tables 6 and 7 present the details.

Table 1: Model Summary 


\begin{tabular}{|l|l|l|l|l|l|}
\hline Model & $\mathrm{R}$ & $\begin{array}{l}\mathrm{R} \\
\text { Square }\end{array}$ & $\begin{array}{l}\text { Adjusted R } \\
\text { Square }\end{array}$ & $\begin{array}{l}\text { Std. Error } \\
\text { of the } \\
\text { Estimate }\end{array}$ & $\begin{array}{l}\text { Durbin- } \\
\text { Watson }\end{array}$ \\
\hline 1 & $.116^{\mathrm{a}}$ & .013 & .009 & 2.75768 & 1.855 \\
\hline
\end{tabular}

a. Predictors: (Constant), age

b. Dependent Variable: Social Media Usage

The study revealed that $1.3 \%$ of the variances of social media usage is explained by age (Table 6). It appears that the contribution of age to social media usage was not significant, $F(1,213)=2.894, p=.090$.

Table 2: Prediction of Age to Social Media Usage

\begin{tabular}{|c|l|l|l|l|l|l|}
\hline \multirow{2}{*}{ Model } & \multicolumn{2}{l|}{$\begin{array}{l}\text { Unstandardized } \\
\text { Coefficients }\end{array}$} & $\begin{array}{l}\text { Standardized } \\
\text { Coefficients }\end{array}$ & \multirow{2}{*}{ Sig. } \\
\cline { 3 - 7 } \multicolumn{2}{|c|}{} & B & Std. Error & Beta & & \\
\hline \multirow{2}{*}{1} & (Constant) & 13.179 & 1.278 & & 10.309 & .000 \\
\cline { 2 - 7 } & Age & -.092 & .054 & -.116 & -1.701 & .090 \\
\hline
\end{tabular}

$F(1,213)=2.894, p=.090$

Findings, as shown in Table 7, showed that age did not significantly predict social media usage, $b=-.092, \mathrm{t}=-$ 1.701, $\mathrm{p}=.090$. Unlike the findings of this study, Lewis (2008) expressed that teenagers have turned out to be familiar with this way of life substantially more than the more older generation, as along this way of living is all they know. It appears youngsters presently utilise social media for most of their everyday activities and data gathering, opposed to older people who utilized assets like the TV or paper.

From Lewis' (2009) perspective, an ongoing overview demonstrated that around 90\% of youngsters in the United States have Internet access, and around seventy-five per cent of these adolescents utilizes social media more than once every day (Kist, 2008). This is inconsistent with the findings of this study. This examination additionally demonstrated that most of the adolescents who have internet access are also individuals of social networking sites, and utilize the internet to make arrangements and associate with companions (Kist, 2008).

\section{Hypothesis Three}

Ho: Social media will not significantly affect student study habit.

This hypothesis sought to test whether social media significantly influence study habit of university students. Simple linear regression was used to test this hypothesis. Tables 8 and 9 present the details.

Table 3: Model Summary

\begin{tabular}{|l|l|l|l|l|l|}
\hline Model & $\mathrm{R}$ & $\mathrm{R}$ Square & $\begin{array}{l}\text { Adjusted } \\
\text { Square }\end{array}$ & $\begin{array}{l}\text { Std. Error of the } \\
\text { Estimate }\end{array}$ & Durbin-Watson \\
\hline 1 & $-.282^{\mathrm{a}}$ & .080 & .075 & 2.63984 & 1.975 \\
\hline
\end{tabular}

a. Predictors: (Constant), Social Media

b. Dependent Variable: Study Habit

The results in Table 8 suggest that $8.0 \%$ of the variances in study habit was explained by social media. The contribution of social media to study habit was found to be significant, $F(1,212)=18.360, p<.001$.

Table 4: Prediction of Social Media Usage on Study Habit

\begin{tabular}{|c|c|c|c|c|c|c|}
\hline \multirow{2}{*}{\multicolumn{2}{|c|}{ Model }} & \multicolumn{2}{|c|}{$\begin{array}{l}\text { Unstandardized } \\
\text { Coefficients }\end{array}$} & \multirow{2}{*}{$\begin{array}{l}\text { Standardized } \\
\text { Coefficients } \\
\text { Beta }\end{array}$} & \multirow[t]{2}{*}{$\mathrm{t}$} & \multirow[t]{2}{*}{ Sig. } \\
\hline & & $\mathrm{B}$ & Std. Error & & & \\
\hline \multirow[t]{2}{*}{1} & (Constant) & 7.889 & .761 & & 10.368 & .000 \\
\hline & Social Media Usage & -.215 & .050 & -.282 & -4.285 & $.000^{*}$ \\
\hline
\end{tabular}


a. Dependent Variable: Study Habit

*significant at .05 level; $F(1,212)=18.360, p<.001$

The findings of the study in Table 9 revealed that social media usage is a significant predictor of study habit, $\mathrm{b}=-.215, \mathrm{t}=-4.285, \mathrm{p}<.001$. Specifically, increased usage of social media resulted in negative study habit. The findings of this study seem to suggest that social media usage influences students' study habit. This supports several other findings by previous studies that social media usage affects academic performance, however, many of these studies found a negative effect of social media usage on student's study habit. Ijeoma and Burke (2013), for example, analysed the attitude of graduate understudies and the degree of utilization of social media post and how this usage affects students' study habit. Ijeoma and Burke (2013) found that social media could negatively affect students' study habit and that planned off programming ought to be introduced in the classes. This contradicts the findings of this study where students were found to use social media for academic course appropriately.

The findings of Munkaila and Iddrisu's (2015) study were consistent with the findings of this study. Munkaila and Iddrisu's (2015) looked at the influence of social media use on student's study habit.in tertiary establishments. In their study, they found that there is no relationship between students' study habit and utilization of social media. Similarly, Akanbi and Anyio (2014), who examined the influence of social media usage on academic performance among SHS students in Ilorin-West Local Government, Kwara State, also found no relationship between social media usage and academic performance.

In Ghana, Owusu-Acheaw and Larson (2015) evaluated students' utilisation of social media and its impact on students' study habit at Koforidua Polytechnic University. The authors found that the examination uncovered that the utilization of social media sites had influenced the academic performance of the respondents adversely and that there was an immediate connection between the utilization of social media sites and students' study habit. In contrast to this present study, social media usage was found to have a positive effect on the study habit of SHS students.

\section{Conclusion}

It can be concluded that university students largely use WhatsApp and Facebook and as such, they visit these social networking sites regularly. Virtually, these two apps can be found on any Android phones which have become a common gadget for university students. This means that if there is addiction, then students would be addicted to the use of Facebook and WhatsApp. Facebook and WhatsApp were mostly used probably not because they are the best social media platforms but because of their popularity. It can be concluded that social media has a negative influence on the study habit of students. Whereas some of the effects of social media improve academic performance, others served as an obstacle for performance. Social media addiction led to poor study habit. If students spend so much time on a social media platform and as well become obsessed with their use, it becomes different for students to concentrate on their academic life. Nevertheless, exposure and use can positively result in better academic performance when used wisely. It is also be concluded that male and female students use social media platforms at the same levels.

\section{Recommendations}

Based on the findings of the study, the following recommendations were made:

1. Since Facebook, WhatsApp, and Instagram were the predominately used social media platforms, the managers of these applications are advised and encouraged to incorporate educative activities in the applications. This should be done such that even if students become addicted to their usage, it will rather improve their study habit.

2. School counsellors together with institutional management should map out strategies to reduce students' addiction to social media platforms. These strategies should include programmes where 
students will be taught how to effectively use social media platforms to improve academic performance.

3. Students and teachers are encouraged to make use of social media platforms to; disseminate educational information, search for relevant information in their area of study, and improve their understanding of issues.

\section{References}

[1] Akanbi, M. I., Anyio, B. T., Ajelabi, S. T. A., \& Mohameed, A. I. (2014). Influence of social media usage on self-image and academic performance among senior secondary school students in Ilorin West Local Government, Kwara State. International Research Journal of Pure and Applied Physics, 2(4), 42-50.

[2] Allen, K. A., Ryan, T., Gray, D. L., McInerney, D. M., \& Waters, L. (2014). Social media use and social connectedness in adolescents: The positives and the potential pitfalls. The Educational and Developmental Psychologist, 31(1), 18-31.

[3] Alnjadat, R., Hmaidi, M. M., Samha, T. E., Kilani, M. M., \& Hasswan, A. M. (2019). Gender variations in social media usage and academic performance among the students of University of Sharjah. Journal of Taibah University Medical Sciences, 14(4), 390-394.

[4] Asemah, E. S., Okpanachi, R. A., \& Edegoh, L. O. (2013). Influence of social media on the academic performance of the undergraduate students of Kogi State University, Anyigba, Nigeria. Research on Humanities and Social Sciences Vol, 3.

[5] Atteh, E., Assan-Donkoh, I., Mensah, Y. A., Boadi, A., Badzi, S. C., \& Lawer, V. T. (2020). A thoughtful overview of social media usage among students and its impact on their academic work. Asian Journal of Advanced Research and Reports, 30-39.

[6] Blankenship, M. (2011). How social media can and should impact higher education. Education Digest, 76(7), 39-42.

[7] Hudson, J. A. (2007). Writing, Technology and Writing Technologies: Developing Multiple Literacies in First-Year College Composition Students. International Journal of Learning, 13(12).

[8] Ijeoma, A., \& Burke, M. (2013). Influence of social media on the behaviour of postgraduate students. A case study of Salford University, United Kingdom. Journal of research and method in /education, 3(6), 39-43.

[9] Kist, W. (2008). Digital literacies: "I gave up MySpace for Lent”: New teachers and social networking sites. Journal of Adolescent \& Adult Literacy, 52(3), 245-247.

[10] Lenhart, A., Purcell, K., Smith, A., \& Zickuhr, K. (2010). Social media \& mobile internet use among teens and young adults. Millennials.

[11] Lewis, B. K. (2009). Social media and strategic communication: Attitudes and perceptions among college students (Doctoral dissertation, Oklahoma State University).

[12] Lim, S., \& Kwon, N. (2010). Gender differences in information behaviour concerning Wikipedia, an unorthodox information source? Library \& information science research, 32(3), 212-220.

[13] Lin, K. Y., \& Lu, H. P. (2011). Why people use social networking sites: An empirical study integrating network externalities and motivation theory. Computers in human behaviour, 27(3), 1152-1161.

[14] Kim, K. S., Sin, S. C. J., \& Tsai, T. I. (2014). Individual differences in social media use for information seeking. The journal of academic librarianship, 40(2), 171-178.

[15] Mazman, S. G., \& Usluel, Y. K. (2011). Gender differences in using social networks. Turkish Online Journal of Educational Technology-TOJET, 10(2), 133-139.

[16] McCarthy, J. (2010). Blended learning environments: Using social networking sites to enhance the first-year experience. Australasian Journal of Educational Technology, 26(6). 
[17] Munkaila, A., \& Iddrisu, A. (2015). The impact of social network sites on the academic performance of students in the polytechnics of Ghana. Internatonal Journal of Economics, Commerce and Management, 3(11), 1021-1035.

[18] Raacke, J. \& Bonds-Raacke, J. (2008). MySpace and Facebook: Applying the users and gratifications theory to exploring friend-networking sites. CyberPsychology \& Behavior, 11(2), 169-174.

[19] Rafferty, F. (2009). Boys should be boys-is it that simple? Education Journal, 116, 32-33.

[20] Reid, D., \& Weigle, P. (2014). Social media use among adolescents: Benefits and risks. Adolescent Psychiatry, 4(2), 73-80.

[21] Sangwaan, R. (2019). Use of social media in education: Positive and negative impact on the students. International Journal on Transformations of Media, Journalism \& Mass Communication (Online ISSN: 2581-3439), 4(2).

[22] Subrahmanyam, K., \& Lin, G. (2007). Adolescents on the Net: Internet use and well-being. Adolescence, 42(168).

[23] Owusu-Acheaw, M., \& Larson, A. G. (2015). Use of social media and its impact on academic performance of tertiary institution students: A study of students of Koforidua Polytechnic, Ghana. Journal of Education and Practice, 6(6), 94-101.

[24] Williams, A. L., \& Merten, M. J. (2009). Adolescents' online social networking following the death of a peer. Journal of Adolescent Research, 24(1), 67-90.

[25] Williams, A. L., \& Merten, M. J. (2011). iFamily: Internet and social media technology in the family context. Family and Consumer Sciences Research Journal, 40(2), 150-170.

[26] Yeboah, J., \& Ewur, G. D. (2014). The impact of WhatsApp messenger usage on students' performance in Tertiary Institutions in Ghana. Journal of Education and practice, 5(6), 157-164. 